\title{
The Analysis of the Relation between Eight-Grade Students' Estimation Performance in Triangles with Their Teaching Style Expectations and Sources of Motivation
}

\author{
Bülent ALTUNKAYA \\ Elementary Mathematics Education, Ahi Evran University, Kırşehir, Turkey \\ Cahit AYTEKIN* \\ Elementary Mathematics Education, Ahi Evran University, Kırşehir, Turkey \\ Bekir Kürşat DORUK \\ Computer Education and Instructional Technology, Abant İzet Baysal University, Bolu, \\ Turkey \\ Bilal ÖZÇAKIR \\ Elementary Mathematics Education, Ahi Evran University, Kirşehir, Turkey
}

\begin{tabular}{|c|c|}
\hline$\overline{\text { tory }}$ & rrade students' estimation achievements in triangles \\
\hline $\begin{array}{l}\text { Received: } \\
04.05 .2014\end{array}$ & $\begin{array}{l}\text { were analysed according to motivation types and knowledge type } \\
\text { expectations. Three hundred and thirty-seven students from three }\end{array}$ \\
\hline $\begin{array}{l}\text { Received in revised form: } \\
03.06 .2014\end{array}$ & $\begin{array}{l}\text { different elementary schools attended in this study. In order to determine } \\
\text { the students' estimation performances, an estimation test in triangles } \\
\text { (ETT) was developed. At the end of the study, it was indicated that the }\end{array}$ \\
\hline $\begin{array}{l}\text { Accepted: } \\
05.06 .2014\end{array}$ & $\begin{array}{l}\text { estimation performances of the students in triangles related with high } \\
\text { level intrinsic motivation and conceptual knowledge expectation. It was }\end{array}$ \\
\hline Key & ndicated that the estimation performances of the students who have \\
\hline $\begin{array}{l}\text { Estimation in Triangles, } \\
\text { Conceptual Learning, Internal } \\
\text { Motivation, Mathematics } \\
\text { Education }\end{array}$ & $\begin{array}{l}\text { extrinsic motivation source were lower. Moreover it was pointed out that } \\
\text { the students expecting procedural knowledge from their teachers had low } \\
\text { level of estimation performance in triangles. This study shows that } \\
\text { estimation skills in triangles, one of the subjects of geometry, are related } \\
\text { with some important variables like motivation types and conceptual } \\
\text { knowledge. There are some important questions that should be answered } \\
\text { by future studies like 'How can students' estimation skills in geometry be } \\
\text { developed? 'How can it be integrated into curriculum? What are the } \\
\text { possible strategies students apply and which factors are they related to?' }\end{array}$ \\
\hline
\end{tabular}

*Correspondence: caytekin1@gmail.com 


\section{Introduction}

In this century, it is very important for students to be able to think critically and examine the validity of the information that they are receiving in their daily life (Sriraman \& Knott, 2009). From this view, estimation and measurement can be seen as basic skills in daily life particularly when it is comes to judging about the results of problems or situations which make sense or not (National Council of Teachers of Mathematics [NCTM], 2000). The importance of estimation skills on mathematics education has been emphasized in many studies. (Levin, 1981; Reys \& Bestgen, 1981; Siegel et al. 1982; Segovia \& Castro, 2009). It was also emphisazed that applying estimation skills promotes conceptual learning in mathematics (MoNE, 2009; Reys et al. 1991; Aytekin, 2012; Olkun \& Toluk Uçar, 2006).

Measurement can be defined as a repeated unit used to determine length, width, area, volume or a weight of something (Workman \& Ahn, 2011). There are lots of situations requiring to make good estimation about measurements and using the estimation when it is necessary to judge about situations where the precise measurement is not needed (Adams \& Harrel, 2010). When people encounter these situations, measurement estimation skills can be very important and useful, since it does not require any measurement tools, therefore people can get a result by performing it very quickly. Measurement estimation can be identified as a critical skill in Mathematics Education (Joram, Subrahmanyam and Gelman,1998). In addition, measurement estimation can be defined as a physical measurement performed without tools (Bright, 1979). Similarly, Reys, Lindquist, Lambdin, and Smith (2009) defined estimation as a process of producing answers that are close enough to allow for good decisions without performing elaborate or exact computations.

Measurement estimation can be seen as one of the fundamental skills that provide understanding the natural world (NCTM, 1996; NCTM, 2000). Estimating about a measurement needs to use mental and visual information to measure without using any measurement tools (Van de Walle et al. 2010). Measurement estimation is heavily depends on previous experience. From this point of view, estimation cannot be seen as a simply guessing. Measurement estimation process includes making a judment about values of measurements. Students use variety of strategy in this process that reflects students' conceptual knowledge in estimated domain (Olkun \& Toluk Uçar, 2006). Teaching and learning how to estimate measurements are very crucial for three reasons. First, it is often needed in daily life, when measurement instruments are absent or inconvenient (Levin, 1981; O’Daffer, 1979). Second, it provides a useful method for teaching physical measurement (Joram et al. 2005). Third reason and more important one is that it provides and reflects a deep understanding (Joram, et al. 2005) in some geometrical concepts like angle and length.

Some of the previous studies have focused on beneficial role for the use of strategies in estimating measurement (Piaget \& Szmanska, 1964; McLaugin, 1981; Segovia, 1997), while others have focused on how it can be developed (Bright, 1979; McLaughin, 1981;Markovits \& Hershkowits, 1993; Pajera, 2001). Siegel, Goldsmiths and Madson (1982) have emphasized the role of mental images to facilitate students' measurement estimation skills. In addition, Reys and others (2009), stated that, students, who are successful in written problems, are not good estimators generally.

Studies related to estimation can be evaluated under two headings: The first one includes operational estimation surveys on decimal numbers, rational numbers, fractions etc. (Bana \& Dolma, 2004; Lemaire at al. 2000; Hanson \& Hogan, 2000; Case \& Sowder, 1990; Leutzinger et al. 1986, Bestgen et al. 1980). The second one includes measurement estimation that 
focused on applying estimation on terms like area, volume, length (Segovia \& Castro, 2009; Siegel et al. 1982; Bright, 1979; Markovitz, 1987; Forrester, 1990). When the literature is reviewed, it is seen that there aren't any studies examining to make estimation on triangles. So that it can be expected that the study focused on estimation skills in triangles would be able to provide valuable data about estimation skill itself and teaching triangles. It is thought that it guides new studies on teaching various geometrical terms applying estimation skills.

\section{Turkish Education System and Estimation}

There has been an on-going change in Turkish education system in last ten years. It can be said that the change started with the project about training teachers and restructuring educational faculties between World Bank and Ministry of Education (Kızılçaoğlu, 2006). The changes started at higher education level at first leaded to a complete change in curriculum of elementary schools from first grades to eight grades in 2004 (Bal, 2008; Bulut, 2006). The changes happened can be seen easily when examining the old and new approaches and contents of mathematics curriculum. The 2004 curriculum emphasized the importance of instructional approaches focusing on conceptual understanding rather than only focusing on procedural knowledge in mathematics education (ERG, 2005). Another important feature of the 2004 curriculum is that it emphasizes on some necessary skills for today's world. These skills are stated as problem solving, reasoning, making connections and communication skills (MoNE, 2009). It is underlined that $21^{\text {st }}$ century is a technology century, it is needed to develop individuals who are able to solve problems and make reasoning (Bulut, 2007). To develop these skills, developed estimation skill is needed. Estimation skill was included also among the general aims of mathematics in previous curricula (MoNE, 1998), but it has been started to be teached with 2004 mathematics curriculum (MoNE, 2009; MoNE, 2013). That can be easily seen in the expressions of the new mathematics curriculum indicating that "to develop estimation skills systematically and mental calculation should be given importance". In the problem solving part of 2004 curriculum, it was stated that making a good estimation and checking the result of a problem are related each other. It is indicated that in order to promote students' reasoning skill, their estimation skills should be developed. Estimation skill is classified as computational estimation and measurement estimation. In the curriculum, it is emphasized that students' estimation skill cannot be developed without any systematic education so it was also advised that teachers should ask students to make estimation, to measure and to control their estimation. It is indicated that such a process is vital for students both to promote their strategies and to develop estimation skills.

Turkish Ministry of Education settled down a new education system called as 4+4+4 in 20122013 academic term (MoNE, 2012). With that system, compulsory education in the country increased from eight years to twelve years (MoNE, 2012). According to this regulation, eightyear-elementary education divided into two terms: the first four-year-level and the secondfour-year level. The first one is called as elementary school, and the second one is called as middle school. In the first four-year level of elementary education, primary school teachers are responsible for most of the lessons included mathematics and Turkish. After this eightyear education all over the country, students have to sit an exam called as OGES (High school entrance exam) to from among different types high schools. Especially in the eighth grade, the level of consciousness of students and parents are increasing. Some of the students believe that they can be successful by memorizing solutions of the previous exam questions and solving similar questions in the exams before while some of them prefer preparing for the exam by analysing and understanding the concepts even if it takes long time (see Table 3). In this point, to develop conceptual understanding, some researchers emphasized that estimation 
skill is related to conceptual understanding rather than memorizing the procedures of estimation skill and practicing (Aytekin, 2012; Olkun \& Toluk Uçar, 2006). In our study, eight grade students' estimation performances on triangles were examined. In order to be successful in the exam of OGES, both conceptual and procedural knowledge are needed. In our study, estimation performances of two group students will be analysed: the first group consists of students who prefer to learn mathematics by focusing on mostly conceptual knowledge and the second group consists of students who prefer to learn mathematics by focusing only memorizing and practicing procedural knowledge. By means of the analyzing the two groups' estimation performance, it is expected to reach new and enlightening knowledge about the relation between estimation skills and conceptual and procedural learning.

\section{The Relation of Conceptual/Procedural Knowledge and Estimation}

To be able to make an efficient estimation is based on understanding mathematics concepts to (Aytekin, 2012; Tekinkır, 2008; Olkun \& Toluk Uçar, 2006). The relationship between expecting conceptual knowledge from teachers and estimation skill was examined in this study. Therefore, it will be necessary to give mostly accepted definitions of conceptual and procedural knowledge is vital. The mostly accepted definitions of conceptual and procedural knowledge are expressed by Hiebert and LeFevre (1986).

Conceptual knowledge is knowledge that is rich in relationships. It can be thought of as a connected web of knowledge, a network in which the linking relationships are as prominent as the discrete pieces of information. Relationships pervade the individual facts and propositions so that all pieces of information are linked to some network. (p. 3)

One kind of procedural knowledge is a familiarity with the individual symbols of the system and with the syntactic conventions for acceptable configurations of symbols. The second kind of procedural knowledge consists of rules or procedures for solving mathematical problems. Many of the procedures that students possess probably are chains of prescriptions for manipulating symbols. (p. 3)

According to these definitions, conceptual knowledge can be seen as relational structure which constitutes of rich knowledge network. On the other hand, procedural knowledge is described as both the signs of mathematics and the knowledge of some rules and procedures applied while solving mathematical problems. One who can understand a concept deeply is expected to able to do all of the operations easily (Maciejewski et al. 2011). When the studies on estimation are examined, it can be easily seen that estimation skill is related to deepness level of one's conceptual knowledge rather than doing operations fast and mentally. To illustrate, most of the items in measurement tools in order to measure students' estimation skills includes questions in which difficult to use memorized procedures without thinking their relations with concepts. (Aytekin, 2012; Reys \& Bestgen, 1981; Reys, Reys \& Penafiel, 1991; Rubenstein, 1985; Levine, 1982). Similarly, it is explained that the students who are successful in estimation tests have deep conceptual understanding and so they can effectively use procedures (Volkova, 2005; Sowder \& Wheeler, 1989; Case \& Okamoto, 1996). For this reason, estimation researches give important information about conceptual and procedural knowledge. Byrnes and Wasik (1991) indicated that conceptual and procedural knowledge require different mental processes. The students who expect for conceptual knowledge mostly focus on making relationships while the students who expect for procedural knowledge focus on only using procedures in order to reach their achieving goals. 
To make connections between procedural and conceptual knowledge also enable students have reasoning skills about the underlying reasons of the procedures and about the effective way of using right procedure at right time (Hiebert \& Lefevre, 1986). The students with deep conceptual knowledge can easily notice their mistakes while applying the procedural knowledge (Byrnes \& Wasik, 1991). The situation is parallel with the observations about estimation skill. The students with high level of estimation skill can easily notice the mistakes during solving questions by understanding the logic of problem result (Aytekin, 2012). Carpenter (1986) found out that the students with developed conceptual knowledge can evaluate the results of using procedures incorrectly during solving fraction problems whether they are logical or not.

Davis (1992) stated that there are two points of view as former and new views in mathematics education. The former view focuses on procedures and rules, on the other and the new one focuses on the meanings and relations rather than memorizing the procedures and the new one indicates that mathematics teaching process is a constructing and making sense process. Similarly Schoenfeld (1990) pointed out that mathematic education should aim conceptual understanding rather than promoting mechanical skills.

Järvelä and Haapasalo (2005) divided students into three groups based on their information expectations. These are procedures oriented students, conceptual oriented students and procedurally bounded students who expect only procedures ignoring their conceptual relations. According to this classification, procedurally oriented students focused on firstly learning procedures then they try to develop conceptual relations of procedures. Conceptual oriented students firstly focus on concepts and then enrich procedural knowledge based on the concepts. The students who only focus on procedural knowledge try to memorize the procedures by exercising repeatedly without focusing on their conceptual relations. A similar classification was made by Entwistle and Tait (1990). In that study, it is pointed out that some students only focus on memorizing the procedures instead of the meaning. But some students try to associate them with prior knowledge and to make sense of new terms by searching for relations. Marton and Säljö (1976) and Entwistle and Tait (1990), indicated that there are two different situations based on learning styles. The first group is expressed as learning focusing on meaning and aiming to making association with prior knowledge. The second group focused on memorizing key points of a topic without making association with prior knowledge. Biggs (1993) stated that the students who study to get the high can be thought as the third group. Especially in the first years of elementary education, teachers are tend to tech procedures mostly, but especially in the university level firstly the concept is described and then practices are made with similar subjects (Haapasalo, 1993). In these two approaches, students' believes about solving mathematical problems are affected in a negative way. Kadijevich and Haapasalo (2001) pointed out that understanding the relations between procedural and conceptual knowledge can be developed with learning activities. Not only the quality of teaching activity but students' attitudes towards learning also affect the speed of this association process. It is a fact that some students focus on memorizing procedures rather than learning for conceptual relations (Lauritzen, 2012). It is needed to find ways of directing these students from expecting only for procedures, to expecting for conceptual knowledge.

In the curriculum of elementary level mathematics in Turkey after 2004 (MoNE, 2009; MoNE, 2013), there are some sentences about conceptual and procedural knowledge like that 'This program emphasizes the process of making relations among concepts and underlying meanings of operations and enriching operation skills". At the core of the program, there are learning zones of concepts and operations. Conceptual approach indicates that much more 
time should be spent to develop students' conceptual basics of mathematical knowledge, so that relations between conceptual and operational knowledge and skills are established. Such a curriculum with that approach can be expected to affect students' estimation skills in a positive way. Even if, it was emphasized to integrate estimation skills with curriculum (Sowder \& Wheer, 1989; NCTM, 1989), there aren't any objective about estimation skills in triangles.

\section{The Knowledge for Real Life and Estimation}

Some students' reason of learning mathematics would be only to be able to solve real life problems which require mathematical information (Lauritzen, 2012). Some of problem solving processes, procedural knowledge is not sufficient, require to be able to associate procedural knowledge with conceptual knowledge.

The compulsory education in Turkey has been eight year-long until 2012. some of the students (\%10,3 for 2010-2011; \%7,44 for 2011-2012; National Education Statistic, 2013) have left from the school after eight year compulsory education. For this reason, it is expected that some of the students who leave the formal education after completing the compulsory education, would focus on only useful information for everyday life. Some would say that there are also many students who think in the same way but not want to leave the formal education. For that reason, in this study it was analyzed that the estimation performances of the students expecting 'the knowledge for real life' and the students who expecting procedural and conceptual knowledge. In this study, the knowledge for real life is described as a kind of knowledge that is evaluated in terms of applying in real life conditions so it doesn't matter whether it is conceptual and procedural knowledge. Many researchers also emphasized that estimation skill is a related and adequate skill for real life (Reys \& Bestgen, 1981; Reys et al. 1991; Rubenstein, 1985; Levine, 1982; Sowder \& Wheeler, 1989; Case \& Okamoto, 1996). From these thoughts, we also decided to analyse students' estimation performance who expect knowledge for real life from teacher.

\section{Types of Motivation and Estimation}

Intrinsic motivation is an incentive situation for individuals themselves to do an activity without any outer effects (Deci \& Ryan, 2000; Deci \& Ryan, 1985) while extrinsic motivation can be defined as getting motivated considering some social factors (Herzberg, Mausner \& Synderman 1959).Passion for success, learning because of wondering are regarded as intrinsic motivation sources while passion for self-realization, exam scores and vocational anxiety are seen as extrinsic motivation sources (Ryan \& Deci, 2000). According to Herzberg and others (1959) intrinsic motivation related to take pleasure from learning content, on the other hand outer factors are related to satisfaction (Akman, 2011). Inner factors motivate individuals at highest levels while outer factors provide appropriate conditions for them to be motivated (Argon \& Ertürk, 2013). In the literature, it is indicated that there is a positive correlation between success in mathematics and motivation types (Volkova, 2005). When the relation between success in mathematics and motivation types is considered, it is expected that the students with higher level of intrinsic motivation are more successful (Evans \& Wedege 2004). It is known that both intrinsic and extrinsic motivation affect students' success positively. In this study, one of the aims is to search the relation between motivation and estimation skill and to analyse the effects of different types of motivation source on students' estimation performance in triangles.

Wæge (2009) mentioned about five variables in the measurement tools in order to be 
developed to determine students' motivation types. The first one is expressed as the focus on learning and understanding beside true answer. The second one is enjoyment of attending mathematical activities and the third is having positive feeling about mathematics and the last two variables are wanting to have risk to solve problems and having self confidence in learning mathematics.

\section{Research Question}

There are two type of estimation research in the literature; these are measurement and computational estimation research. In this study, students' measurement estimation performances on triangles have been analysed. Measurement estimation generally is a way of creating an approximate answer by comparing qualities like area, volume, length and angle to reference points in mind without applying a measurement tool. Measurement activities require the integration of spatial and numerical concepts into the situations with unifying idea of an iterated unit (Hiebert, 1981). Measurement estimation in triangles is very different from estimation in other areas that every dimension can be thought separately. Measurement estimation in triangles involve the coordination of angle, length and other concepts which only be used in geometry like bisector, median, congruent and similarity. In this article, we investigated eight grade students' measurement estimation performance in triangles and its relation to some variables like knowledge type expectation and source of motivation for studying mathematics in Turkey. The main problem of the study is the question 'Do the eighth grade students' estimation achievements in triangles differ from each other according to their knowledge type expectations and motivation sources types?'

\section{Methodology}

\section{Participants}

The subjects were 337 students studying in the 8th grade from three public middle schools in the city center of Kırşehir from Turkey. The subjects participated in the study were selected by convenience sampling procedure. These schools were selected in order to represent general characteristics of the middle schools in Kırşehir.

\section{Instruments}

In this study there were two instruments. One of them was Estimation Test in Triangles (ETT). The ETT was developed by the four researchers who are specialist in mathematics education to measure the performance of students' measurement estimation ability in triangles.

The test was piloted before the study to check its reliability, appropriateness, discrimination of items and to determine difficulty of questions. In the development process of the ETT, firstly four researchers wrote 42 multiple-choice questions according to seven objectives (principles) of 8th grade mathematics. These objectives were taken from Elementary School Mathematics Curriculum and listed in table 1. (MoNE, 2009). In the following objectives, there aren't any objectives about triangle area. The reason for that is in elementary mathematics curriculum (MoNE, 2009), area subject is included in measurement learning part, not in geometry. In this study, the objectives about triangles in eight grade mathematics lesson are indicated. 
Table 1. Objectives of the Estimation Test in Triangle.

\begin{tabular}{l}
\hline Objectives \\
$\begin{array}{l}\text { Be able to determine the relation of the sum or the difference of the lengths of any two sides between } \\
\text { the length of the remaining side }\end{array}$ \\
\hline Be able to determine the relation of the lengths of each sides with the opposite angles of each sides \\
\hline Be able to draw a triangle with given measures of the sufficient elements \\
\hline Be able to construct perpendicular bisector, angle bisector and altitude of a triangle. \\
\hline Be able to explain the equality terms associated with triangles. \\
\hline Be able to explain the similarity terms associated with triangles. \\
\hline Be able to construct Pythagoras relation
\end{tabular}

The questions of the ETT were checked for their appropriateness and clarity of the items by two researchers with doctoral degree and one graduate student in the field of Elementary Mathematics Education. According to their feedback some changes were made and the ETT was made ready for pilot study. 38 multiple-choice items had been decided to use in pilot study. The language of the items in ETT was Turkish.

The participants of the pilot study were 187 students ( 87 famale, 100 male) from three public middle schools in city center of Kirşehir. An item analysis test was conducted and according to its result, discrimination indices of eight items of ETT were not satisfactory. Their discrimination indices were below 0.20. Therefore, these questions were excluded from the final version of the ETT. Cronbach's alpha reliability coefficient of the ETT was found as 0.79 for the pilot study. According to result of the pilot study, the final version of ETT included 30 multiple-choice items. In figure 1, four items of the ETT were represented as examples.

The final version of ETT was administrated 337 students (172 female, 165 male) in the study. Cronbach's alpha reliability coefficient was found as 0,808 . Average difficulty of the final version of the ETT was found as .59, discrimination index was found as .52.

In addition, a survey was prepared to determine students' believes about their achievement in mathematics and their opinions about mathematics education. In this survey there were six questions and these questions were about the expectation of math grade at the end of the semester, the perception level of students about the relationships between mathematics and real life, the perception of teachers/parents evaluation of their mathematical proficiency, the students' motivation types of doing mathematics and the students' expectation of knowledge types from their teachers. All researchers had reached a consensus about all survey questions and items of ETT were suitable for the purpose and clarity of the questions and items were appropriate for eighth graders in Turkey. In that study, the relation between students' responses about motivation types and knowledge types expectations in the questionnaire and their estimation success level are focused. 
Figure 1. Examples of Estimation Test in Triangle*

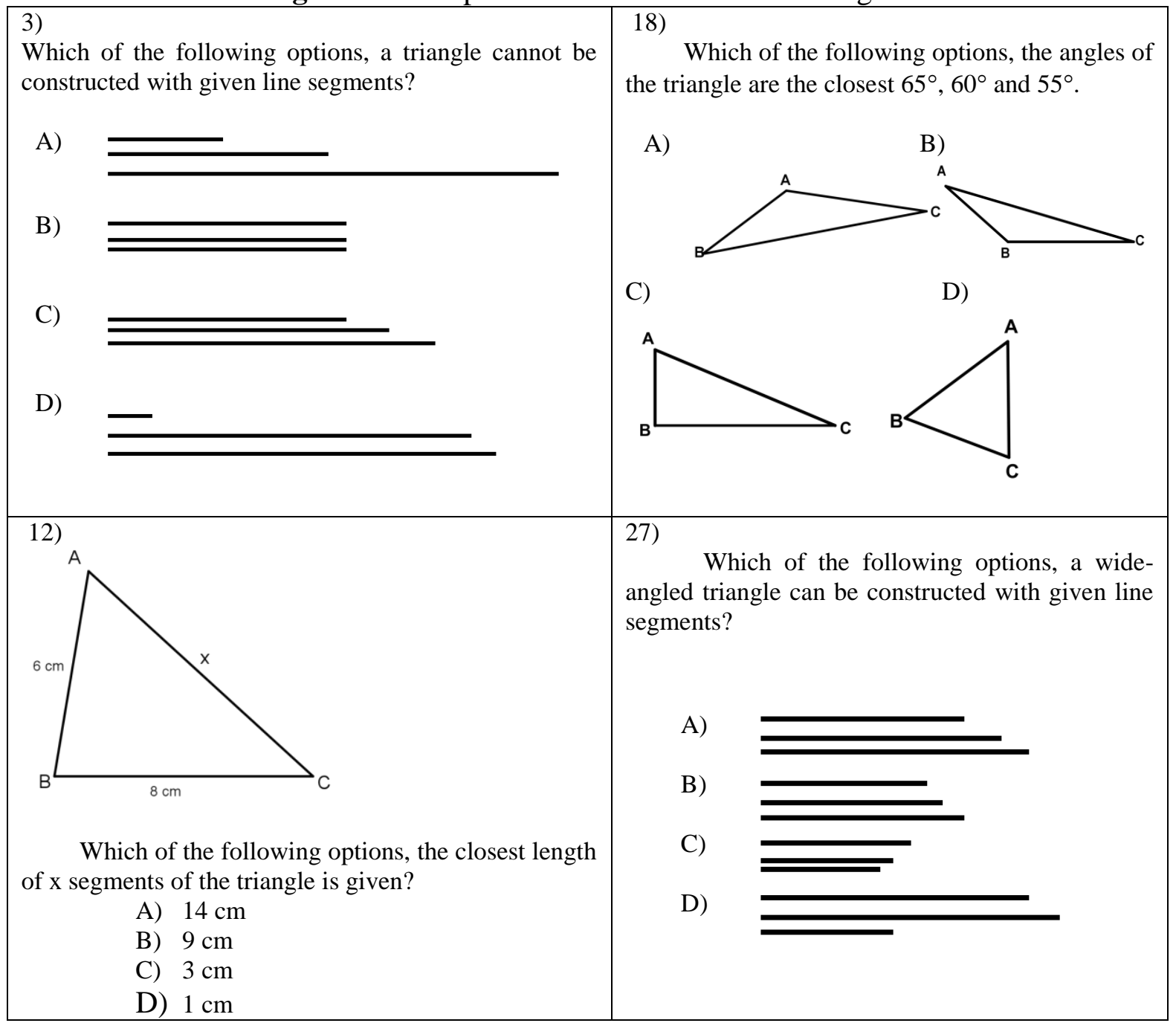

*The actual version of the ETT was developed in Turkish by authors of this article. The examples of items given here were translated by the authors from Turkish to English.

\section{Procedure}

In the beginning of the study, it was explained to students that it was an estimation test, so there was no need to use paper and pencil computation. Students were asked to estimate the closest values of given shapes, and decide which choice was the most senseful.

Before the administration of the ETT, a survey which included six questions was administrated to students. In this study, two of the questions in the questionnaire are accepted as the independent variable. The analysis of the other questions in the questionnaire is not included in this study. The first one was motivation types that students regard as their reason for their studying maths and the other one was knowledge type expectation from their teachers. And the success levels of estimation in triangle were examined in that study.

\section{Data Analysis}

The sentences were prepared for knowledge type expectation by researchers. The students would select the most appropriate one for themselves were examined in three groups while analysing the data. The first group sentences included procedural knowledge and the 
second one included conceptual knowledge and the last one included everyday life knowledge. This classification was in accordance with the classification of Hiebert and LeFevre (1986). There were also types of sentences that the students use mostly about the sources of motivation. The students who chose the sentences like "I'm studying mathematics because of not getting poor mark, I have to study mathematics in order to get the profession which I want in the future, I want to prove myself to my social surroundings by studying mathematics" have extrinsic motivation. On the other hand the students who chose the sentences like "I'm studying only interesting topics of mathematics, I'm interested in all topics of mathematics and I want to learn all of them" have intrinsic motivation. The classification of those sentences is parallel with the study conducted on motivation types by Deci and Ryan (2000).

None of the subjects had a systematic education about estimation ability in geometry. One lesson hour (40 minutes) was given to students to complete ETT and six survey questions. During the implementation of the ETT, it was observed that the duration was enough for all students. In order to analyse the data Tamhane T2 test was conducted since Levene's equal variance assumption was not satisfactory.

\section{Findings}

At the end of the analysis of data obtained from the study, there found out significant differences on the levels of estimation skills usage on triangles among the groups based on motivation types and teaching styles expected from the teachers. There were not significant differences between males and females about their estimation performances ( $p>0,05)$. It was found out that generally all of the students had lower achievement mean scores of estimation of triangles (see Table 2).

Table 2. Mean scores of estimation of triangles of male and female and t-test results

\begin{tabular}{|c|c|c|c|c|c|c|}
\hline Gender & $\begin{array}{l}\text { Mean } \\
\text { (M) }\end{array}$ & $\begin{array}{l}\text { Number of } \\
\text { students }(\mathrm{N})\end{array}$ & $\begin{array}{l}\text { Standart } \\
\text { deviation }\end{array}$ & $\mathrm{df}$ & $\mathrm{t}$ & $\mathrm{p}$ \\
\hline Male & 18,10 & 165 & 5,823 & \multirow{3}{*}{335} & \multirow{3}{*}{1,171} & \multirow{3}{*}{0,243} \\
\hline Female & 17,41 & 172 & 5,079 & & & \\
\hline General & 17,75 & 337 & 5,459 & & & \\
\hline
\end{tabular}

\section{Source of Motivation and Estimation of Triangles}

Table 3. The source of students' motivation of studying mathematics and the achievement scores from ETT

\begin{tabular}{|c|c|c|c|c|}
\hline Source & $\begin{array}{c}\text { Sentences of students' motivation studying } \\
\text { mathematics }\end{array}$ & $\mathbf{N}$ & Mean & Sd \\
\hline \multirow[t]{3}{*}{$\begin{array}{l}\text { External } \\
\text { Motivation }\end{array}$} & $\begin{array}{l}\text { I'm studying mathematics because of not getting } \\
\text { poor mark }\end{array}$ & 52 & 14,38 & 5,664 \\
\hline & $\begin{array}{l}\text { I have to study mathematics in order to get the } \\
\text { profession which I want in the future. }\end{array}$ & 62 & 17,03 & 5,182 \\
\hline & $\begin{array}{l}\text { I want to prove myself to my social surroundings } \\
\text { by studying mathematics }\end{array}$ & 59 & 16,20 & 5,195 \\
\hline \multirow[t]{2}{*}{$\begin{array}{l}\text { Internal } \\
\text { Motivation }\end{array}$} & $\begin{array}{l}\text { I'm studying only interesting topics of } \\
\text { mathematics. }\end{array}$ & 23 & 20,09 & 4,457 \\
\hline & $\begin{array}{l}\text { I'm interested in all topics of mathematics and I } \\
\text { want to learn all of them }\end{array}$ & 141 & 16,91 & 6,201 \\
\hline
\end{tabular}


From Table 3, it can be understood that the number of students choosing the sentence 'I'm studying only interesting topics of mathematics.' had highest mean to the rest of the students who choose other sentences from the questionnaire. The students' estimation performances who chose these sentences "I have to study mathematics in order to get the profession which I want in the future, I'm interested in all topics of mathematics and I want to learn all of them, I want to prove myself to my social surroundings by studying mathematics" were close each other. The students who chose the sentence as their motivation source "I'm studying mathematics because of not getting poor mark" have the lowest ETT mean scores.

Table 4. The results of the independent sample t-test for the source of motivation and the achievement scores from ETT

\begin{tabular}{llllll}
\hline & $\mathbf{N}$ & Mean & Sd & t & p \\
\hline $\begin{array}{l}\text { External } \\
\text { Motivation }\end{array}$ & 173 & 15,95 & 5,415 & & \\
$\begin{array}{l}\text { Internal } \\
\text { Motivation }\end{array}$ & 164 & 19,64 & 4,845 & $-6,574$ & 0,000 \\
\hline
\end{tabular}

When the ETT scores of the groups based on their motivation sources are analysed, it is concluded that as seen in the table 4 the students who have internal motivation sources have higher ETT scores than the students who have external motivation source.

\section{Knowledge Types Expectations and Estimation}

When the findings of the questionnaire are analysed, there are some differences about students' expectation types for knowledge from their teachers. Some students expect that they learn the necessary rules and procedures they believe as helpful in OGES and solve examples so that they can apply these procedures while the other students expect useful knowledge for everyday life. These classifications can be seen as the prior expectations of students. In a similar way, a student can want to both understand the concept and to apply procedures effectively. The classification of that study is evaluated as prior expectation. In order to make a comparison about estimation success, the sentences the students chose in the questionnaire are classified as: expectation for procedural knowledge, expectation for conceptual knowledge and expectation for knowledge in daily life.

Table 5. Students' expectation types from teachers about teaching mathematics and the achievement scores from ETT

\begin{tabular}{|c|c|c|c|c|c|}
\hline Students' choices of learning & $\mathbf{N}$ & Mean & Sd & Minimum & Maximum \\
\hline Unstated & 3 & 17,00 & 4,359 & 14 & 22 \\
\hline $\begin{array}{l}\text { The teacher has to show me the better } \\
\text { method of memorize the } \\
\text { mathematical procedure and to solve } \\
\text { lots of different problem type to be } \\
\text { successful in OGES }\end{array}$ & 204 & 16,77 & 5,328 & 4 & 28 \\
\hline $\begin{array}{l}\text { The teacher has to teach me the } \\
\text { meaning of procedure and support us } \\
\text { to find different solutions of } \\
\text { problems. }\end{array}$ & 116 & 19,72 & 4,886 & 5 & 30 \\
\hline $\begin{array}{l}\text { The teacher has to teach me useful } \\
\text { information in daily life than } \\
\text { preparing exams }\end{array}$ & 14 & 15,71 & 7,660 & 3 & 26 \\
\hline Total & 337 & 17,75 & 5,459 & 3 & 30 \\
\hline
\end{tabular}


As seen clearly in the table 5, the students expecting lessons based on meanings of concepts, rules and procedures instead of only rules and procedures have higher scores of ETT than the other. There is only one point difference between the scores of the students expecting only knowledge types and students expecting only knowledge about everyday life. However there are three points difference between the students expecting rules and procedures and the students expecting knowledge about meanings of concepts, rules and procedures.

Table 6. Levene's test of Equality Error Variance for Students' expectation types from teachers about teaching mathematics

\begin{tabular}{llll}
\hline \multicolumn{2}{l}{ Test of Equality of Variance } & & \\
\hline $\mathrm{F}$ & $\mathrm{df} 1$ & df2 & Sig. \\
\hline 3,693 & 3 & 333 & 0,013 \\
\hline
\end{tabular}

In order to determine whether the variance of students' ETT scores in the groups formed based on knowledge types they expect to learn is homogenous or not, Levene test was conducted. Because the test the variance in the group is not homogenous, an appropriate test for such a situation, Tamhane T2 test was conducted.

Table 7. The results of Tamhane T2 test for the Students' expectation types of knowledge from teachers about teaching mathematics

\begin{tabular}{llll}
\hline $\begin{array}{c}\text { Students' expectation types } \\
(\mathbf{i})\end{array}$ & \multicolumn{1}{c}{$\begin{array}{c}\text { Sudents' expectation types } \\
(\mathbf{j})\end{array}$} & $\begin{array}{c}\text { Mean differences } \\
(\mathbf{i}-\mathbf{j})\end{array}$ & p \\
\hline Procedural knowledge & Conceptual knowledge & $-2,950^{*}$ & 0,000 \\
\cline { 2 - 4 } & Knowledge for daily life & 1,060 & 0,997 \\
\hline Conceptual knowledge & Procedural knowledge & $2,950^{*}$ & 0,000 \\
\cline { 2 - 4 } & Knowledge for daily life & 4,010 & 0,378 \\
\hline Knowledge for daily life & Procedural knowledge & $-1,060$ & 0,997 \\
\cline { 2 - 4 } & Conceptual knowledge & $-4,010$ & 0,378 \\
\hline
\end{tabular}

According to the results of Tamhane $\mathrm{T} 2$ in Table 7, it is seen that there is a significant difference between the ETT scores of the students indicating that they want to study mathematics to prepare for exams and the ones indicating that they want to study mathematics to understand it.

\section{Discussion}

The research findings indicate the success of applying estimation skill in triangles is affected by motivation sources. It draws attention that the students who study mathematics only for not getting poor grades have lower estimation performance in triangles. Most of the studies on motivation make explanation about enjoyment of a discovery reached via brain, being proud of doing an activity, getting happy to learn without mark anxiety. This motivation type is called as intrinsic motivation. The study finding is parallel with the idea of Covington (1999) about that the students who do not have score anxiety and have higher level of intrinsic motivation have higher level of academic success.

The study presents there can be some discussion about the study results of Covington and Dray (2002). They expressed that expectations to get higher scores for secondary school students are much more effective than intrinsic learning passion. However our study result showed that the students who study aiming to get high scores have rather low academic success in applying estimation skill in triangles. The students who acquire procedures to study exams may be more successful in ordinary exams than the students who focus on conceptual understanding. But the test in the study requires using estimation skill in triangles 
as a life skill so it is getting harder for the students to solve the questions by using only procedural knowledge. Getting high scores seen as a tool of proving themselves by students. If the teachers give importance to procedural knowledge and ask questions in exams about conceptual understanding and estimation, the students who want to get high scores and prove themselves have to act in accordance with the teachers' expectation. For that reason studying with the aim of getting high scores can affect applying estimation skills in different areas positively if teachers' criteria is giving the high grade focused on estimation skill and conceptual understanding. However in our study it is seen that the expectation for getting high scores does not affect the success of applying estimation skill in triangles as much as expected. That expectations or scare of high scores prevent meaningful learning is a commonly expressed point in different studies (Covington \& Omelich, 1984). As a matter, of course, students who don't give importance to meaningful learning and put the aim of getting high mark in the first place, have difficulty in estimation, which is related to conceptual learning closely.

Many studies show that intrinsically motivated students have higher achievement level, lower anxiety level and are aware of their own talents (Gottfried, 1982). Students' intrinsic motivation provides successful studies and this success increases the intrinsic motivation, too (Harter \& Connell, 1984). The students choosing the sentence ' I'm studying only interesting topics of mathematics." in the questionnaire have rather high level of estimation mean scores. Such students can be said to have intrinsic motivation. According to the results of t-test, estimation achievement of the students with intrinsic motivation is higher than the one of those with extrinsic motivation and the difference is significant statistically, too. Many studies pointed out students with intrinsic motivation are much more successful (Yates, 2000; Wedege \& Evans, J. 2006; Ryan \& Deci, 2000). Similarly, the study indicated the students with intrinsic motivation are much more successful in estimation in triangles.

The students choosing the sentence "I'm studying only interesting topics of mathematics." in the questionnaire are tend to behave independently from curriculum and school system. The study result shows that the estimation success of these students is statistically significant higher in estimation than the others. In other words, if students are given the chance to study freely and behave freely in the school, they can be intrinsically motivated in both primary and secondary schools (Deci et al., 1991; Grolnick \& Ryan, 1987) and this may causes the higher estimation performance in triangles.

Some students tend to memorize procedures rather than relations among mathematical concepts (Lauritzen, 2012). As seen in the Table 5, two hundred four of the students attended in the study expressed that if teachers solve much more similar exercises, show short ways of solution, they believe they can be more successful. This kind of knowledge is called as procedural in the literature. Conceptual understanding is seen as a conscious thinking activity (Hiebert \& Lefevre, 1986). As seen in the Table 5, one hundred and sixteen of the students attended in the study expected to learn the meaning of procedures. Only fourteen of the students expressed they expected to learn the knowledge for real life. At the end of the analysis, the students expecting conceptual knowledge have higher ETT scores than the others have. It is seen that more than half of the students expected procedural knowledge. According to result of analysis, there are no significant differences between these two groups. The students' estimation successes who expect only procedural knowledge and the knowledge for real life are lower than the ones who expect conceptual knowledge. This shows that the instruction based on conceptual knowledge and meaning is effective for estimation success. If the students have the chance to attend in discussions in the class and are directed to solve 
problems about mathematical thinking, and if their answers are evaluated to explain their reasoning habit and to compare different solution ways, the students' conceptual thinking and problem solving skills are developing (Gearhart et al., 1999) and so their estimation skills are developing, too.

If we hope an education focusing on conceptual knowledge more than procedural knowledge, we should form our assessment standards (Schoenfeld, 1982). Because the students face to exams requiring only procedural knowledge, they are getting eager to memorize procedural knowledge than taking attention to conceptual knowledge (Lauritzen, 2012). The findings of the study show that believes of students about learning mathematics affect their success in estimation achievement in triangles. So it can be indicated the students expecting procedural knowledge believe they will be successful in that way and they perform weakly than the students focusing on meanings do. It is impossible to have an effective mathematics education without focusing on development of conceptual understanding. In this study, $60 \%$ of the students prefer procedural knowledge (Table 5). Similarly in the reports of NAEP (1993), it is pointed out that about $90 \%$ of the students believe there is a procedural process and the process should be remembered. This approach is resulted from only focusing procedural knowledge in lessons. The teachers with teaching styles focusing on providing procedure firstly show the procedures and then solve various exercises in which the same procedures should be followed. The style leads that students see mathematic learning as a lesson of procedures to be memorized rather than a meaning research process. When it takes into attention that making estimation is a skill based on conceptual understanding rather than procedures, it is very essential to direct students to conceptual knowledge.

\section{Conclusion}

The results of the study suggest that intrinsically motivated students are statistically significantly more successful in their estimation performance in triangles. For this reason, the activities that improve their intrinsic motivation level are very important to increase their estimation ability. It is known that instructional activities that aim to help students understand concepts are crucial to raise students' intrinsic motivation (Covington and Dray, 2002). Owing to the fact that there were limited items in the questionnaire used in this study, it is necessary to conduct more detailed studies with questionnaires including more items to reach more comprehensive data that will show the relationship between types of motivation and estimation success. According to the findings of this study, it can be said that intrinsically motivated students could integrate their competence in triangles to the ability of estimation.

At the end of the study, it was seen that the students focused on high scores showed lower success in their estimation. It can be said that this kind of students do not consider mathematics as a part of real life but as a procedure irrelevant to real life and that should be learnt to reach external goals. As a result of the exam-oriented education system, students have to pass exams in which mathematics has an important place to be able to reach certain targets. Therefore, families at home and teachers at school force students to be exam-oriented and this pressure may cause students to learn mathematical knowledge and procedures instead of acquiring them by connecting them to their life. This situation brings about people not being able to see how mathematics function in real life and people with lack of ability to use mathematics in their life effectively. Such students may have difficulties solving the problems in which they have to use their estimation ability that is relevant to conceptual learning rather than procedural knowledge. For this reason, it is vital that the questions asked in the exams in schools and in the university entrance exams measure conceptual understanding more. 
It draws attention that the estimation average of the students marking the item "I am studying only interesting topics of mathematics" among the items on the sources of motivation is much higher than the others. This result can be considered as expected as the role of "interest" in learning has long been accepted largely in literature. This situation of the students who marked the item "I am studying only interesting topics of mathematics" as their reason to study can be evaluated as meeting the students' need for autonomy. In this context, it can be said that this choice contributes well to their intrinsic motivation.

Most studies show that in secondary schools, studying induced by intrinsic motivation changes into learning to get higher scores (Eccles, et al., 1993). In this study, extrinsically motivated secondary school students induced to study in order to prove themselves to the other people around, get a good job, or not to get a low remark have much lower estimation ability than the students in the other group. For this reason, it can be recommended that conceptual learning methods and process evaluation techniques be utilized and thus students be kept away from the rivalry environment that blocks their being intrinsically motivated learners. Furthermore, it is thought that utilizing estimation skills in instruction and assessments leads students to acquire conceptual knowledge and thus contributes well to their motivation positively since the students with good conceptual competence enjoy finding various and different solution methods and getting approval and appreciation of others. However, most of the extrinsically motivated students do not value the results of their successful attempts because they do them reluctantly and with a fear of failure.

Another important finding of the study is that the points that the students who expect to get conceptual knowledge are statistically higher than those that the students who expect to get procedural knowledge. If the test had consisted of the questions measuring the knowledge about triangles, the students who prefer procedural knowledge might have been more successful. However, when the need to integrate mathematical knowledge to the estimation ability occurred, the students who were not able to achieve conceptual learning might have difficulties in such a test. For this reason, to be able to grow people with good ability to make use of mathematics in their personal life effectively, conceptual learning should be emphasized more. Since the estimation ability requires conceptual understanding, the activities that deepen and focus on conceptual understanding contribute well to students' success in estimation positively. However, it is stated that a student who has only conceptual knowledge but cannot do the calculations well does not feel good. Likewise, a student who can only do the calculations well but does not know the meanings does not consider himself as good at mathematics (Lauritzen, 2012).

Ma (1999) states that knowledge levels of teachers affect their teaching strategies. From this point of view, it is clear that there is a relationship between instructional methods and focused knowledge types. For example, it can be observed that in the environment where the teachers are the people who transfer the related knowledge and there is little in-class communication, procedural skills are stressed more and thus they improve (Cobb, 1988). To improve estimation skills, it is necessary to focus on the meanings of the procedures rather than procedures only.

Motivation researchers stress that an education system with focus on daily life increases student motivation, too. It is stated that if during instruction, teachers encourage students to connect whatever is learned to their daily life, this increase the personal interest and enhances meaningful learning in students. Motivation researchers state that instructions connected to students' daily life increase student attention and thus induce them to try harder to learn 
(Krapp, 1999). However, in this study, the estimation success averages of the students who expect knowledge for everyday life are observed much lower than the others. It is thought that this situation may be due to instructions with focus on procedures in an exam-oriented system and with no connection to the conceptual basics and real life and thus students' expectations are not satisfied.

This study was carried out with limited number of items of questionnaire, so it is needed to conduct new studies on the relation between motivation types and estimation achievement in order to get deeper data. Moreover, this study shows that estimation skills in triangles, one of the subjects of geometry, are connected with some important variables like motivation types and conceptual knowledge. There are some important questions that should be answered by future studies like 'How can students' estimation skills in geometry be developed? 'How can it be integrated into curriculum? What are the possible strategies students apply and which factors are they related to?'

\section{Acknowledgement}

This research has been supported by Ahi Evran University: PYO-EGF.4001.13.003

\section{References}

Adams, T.L. and Harrel, G. (2010). A Study of Estimation by Professionals at Work. Journal of Mathematics \& Culture,November, 5 (2)

Akman, H. (2011). İçsel ve Dışsal Motivasyon Unsurlarına Illişkin Türk Telekomünikasyon A.Ş.'de Çalışanlar Üzerinde Bir Araştırma [A research on the impacts on the engineers and them technicians working for Türk Telekominikasyon A.S.S. of internal and external factor of motivation]. Süleyman Demirel Üniversitesi Sosyal Bilimler Enstitüsü İşletme Anabilim Dalı Yüksek Lisans Tezi

Argon, R., \& Ertürk, R. (2013). İlköğretim okulu öğretmenlerinin içsel motivasyonları ve örgütsel kimliğe yönelik algıları[Intrinsic Motivations of Primary School Teachers and Their Perceptions of Organizational Identity].Kuram ve Uygulamada Ĕ̈itim Yönetimi [Educational Administration: Theory and Practice], 19(2), 159-179.

Aytekin, C. (2012). Illköğretim ikinci kademe öğrencilerinin kesirlerde tahmin becerilerinin incelenmesi [Investigation of middle school students' estimation ability with fractions]. Yayımlanmamış Yüksek Lisans Tezi, Bolu: Abant İzzet Baysal Üniversitesi Eğitim Bilimleri Enstitüsü.

Bal, A.P. (2008). Yeni İlköğretim Matematik Öğretim Programının Öğretmen Görüşleri Açısından Değerlendirilmesi[The Evaluation of new mathematics curriculum in term of teacher perpectives]. Ç. Ü. Sosyal Bilimler Enstitüsü Dergisi, Cilt 17, Sayı 1, s.5368

Bana, J.\& Dolma,P.(2004). The relationship between the estimation and computation abilities of year 7 students. [20.11.2010] http://www.merga.net.au/documents/RP52004.pdf

Berger, P. L., \& Luckmann, T. (1996). The Social Construction of Reality. New York: Anchor.

Bestgen, B. J., Reys, R. E., Rybolt, J. F. ve Wyatt, J. W. (1980). Effectiveness of systematic instruction on attitudes and computational estimation skills of preservice elementary teachers. Journal for Research in Mathematics Education, 11, 124-135.

Biggs, J. (1993). What do inventories of students" learning processes really measure? A theoretical review and clarification. British Journal of Educational Psychology, 63(3-19). 
Bright, G.W. (1979). Measuring experienced teachers' linear estimation skills at two levels of abstraction. School Science and Mathematics, 79, 161-64.

Bulut, İ. (2006) Yeni İlköğretim Birinci Kademe Programlarının Uygulamadaki EtkililiğininDeğerlendirilmesi [An evaluation of the effectiveness of the new primary school curricula in practice, Unpublished Dissertation], Frrat Üniversitesi, Sosyal Bilimler Enstitüsü, Eğitim Bilimleri Anabilim Dalı, Elazığ

Bulut, M. (2007). Curriculum reform in Turkey: A case of primary school mathematics curriculum. Eurasia Journal of Mathematics, Science \& Technology Education, 3(3), 203-212.

Byrnes, J. P., \& Wasik, B. A. (1991). Role of Conceptual knowledge in Mathematical Procedural Learnig. Developmental Psychology, 27(5), 777-786.

Carpenter, T. P. (1986). Conceptual Knowledge as a Foundation for Procedural Knowledge. In J. Hiebert (Ed.), Conceptual and Procedural Knowledge: The Case of Mathematics. Hillsdale, NJ: Erlbaum, 113-132.

Case, R. ve Okamoto, Y. (1996). The role of conceptual structures in the development of children's thought. Monographs of the Society for Research in Child Development, 61, $1-2$.

Case, R. ve Sowder, J.T. (1990). The development of computational estimation: a neopiagetion analysis. Cognition and Instruction, 7, 79-104.

Cobb, P. (1988). The Tension Between Theories of Learning and Instruction in Mathematics Education. Educational Psychologist, 23(2), 87-103.

Covington, M. V. and Dray E. (2002). The Developmental Course of Achievement Motivation: A Need Based Approach. Development of achievement motivation. Academic press.

Covington, M. V. (1999). Caring about learning: The nature and nurturing of subject matter appreciation. Educational Psychologist, 34(2), 127-136

Covington, M. V. and Omelich, C.L. (1984). Controversies or consistencies? A reply to Brown and Weiner. Journal of Educational Psychology, 76, 159-168.

Davis, R. B. (1992). Understanding "Understanding". Journal of Mathematical Behavior, 11, 225-241.

Deci, E. L., \& Ryan, R. M. (2000). The "What" and "Why" of Goal Pursuits: Human needs and the Self-Determination of Behavior. Psychological Inquiry, 11(4), 227-268.

Deci, E. L., Vallerand, R. I., Pelletier, L. G., \& Ryan, R. M. (1991). Motivation and education: The self-determination perspective. Educational Psychologist, $26(3 \&$ 4), 325-346.

Deci, E., \& Ryan, R. (1985).Intrinsic motivation and self-determination in human behavior. New York: Plenum Press.

Eccles, 1. S., Wigfield, A., Midgley, C, Reuman, D., Maclver, D., \& Feldlaufer, H. (1993). Negative effects of traditional middle schools on students' motivation. The Elementary School journal. 93(5), 553-574.

Entwistle, N., \& Tait, H. (1990). Approaches to learning, evaluations of teaching, and preferences for contrasting academic environments. Higher Education, 19, 169-194.

ERG.(2005). Yeni Öğretim Programını İnceleme ve Değerlendirme Raporu, online source, [http://www.erg.sabanciuniv.edu/docs/mufredat_raporu.doc] Date: 22.05.2006.

Evans, J., \& Wedege, T. (2004). Motivation and resistance to learning mathematics in a lifelong perspective. The 10th International Congress on Mathematical Education, [http://www.icme10.dk/], TSG 6, Copenhagen, Denmark.

Forrester, Michael A.(1990). Exploring estimation in young children.Educational Psychology, $4(10)$. 
Gearhart, M., Saxe, G. B., Fall, R., Schlackman, J., Nasir, N., Ching, C. C., Bennett, T. R., Rhine, S., \& Sloan, T. (1999). Opportunities to learn fractions in elementary mathematics classrooms. Journal for Research in Mathematics Education, 30, 286315.

Gottfried, A. E. (1982). Relationships between academic intrinsic motivation and anxiety in children and adolescents. Journal of School Psychology, 20, 205-215.

Grolnick, W. S., \& Ryan, R. M. (1987). Autonomy in children's learning: An experimental and individual difference investigation. Journal of Personality \& Social Psychology, 52(5), 890-898

Haapasalo, L. (1993). Systematic Constructivism in Mathematical Concept Building. In P. Kupari \& L. Haapasalo (Eds.), Constructivist and Curricular Issues in the School Mathematics Education. Mathematics Education Research in Finland. Yearbook 1992-1993. University of Jyväskylä. Institute for Educational Research. Publication Series B, Theory and Practice 82. University of Jyväskylä \& The Finnish Association of Mathematics and Science Education Research, 9-22.

Hanson, S.A. ve Hogan P.T., (2000). Computational estimation skill of college students. Journal for Research in Mathematics Education, 4(31), 483-499.

Harter, S., \&Connell, I. P. (1984). A comparison of alternative models of the relationships between academic achievement and children's perceptions of competence, control and motivational orientation. In I. Nicholls (Ed.), The development of achievement-related cognitions and behaviors. Greenwich, CT: 1AI Press.

Herzberg, F., Mausner, B., \& Snyderman, B. (1959). Motivation to Work. New York: John Wiley.

Hiebert, J. (1981). Cognitive development and learning linear measurement. Journal for Research in Mathematics Education, 12(3), 197-211.

Hiebert, J., \& Lefevre, P. (1986). Conceptual and procedural knowledge in mathematics: An introductory analysis. In J. Hiebert (Ed.), Conceptual and procedural knowledge: The case of mathematics (pp. 1-27). Hillsdale, NJ: Erlbaum.

Järvelä, J., \& Haapasalo, L. (2005). Three Types of Orientations by Learning Basic Routines in ICT. Paper presented at the Learning and Instruction on Multiple Context and Settings III. Proceedings of the Fifth Joensuu Symposium on Learning and Instruction. , Joensuu.

Joram, E., Gabriele, A. J.,Bertheau,M.,Gelman, R.\&Subrahmanyam, K. (2005). Children's use of the reference point strategy for measurement estimation. Journal for Research in Mathematics Education, 36(1),4-23.

Joram, E., Subrahmanyam, K. ve Gelman, R. (1998). Measurement Estimation: Learning to Map the Route from Number to Quantity and Back. Review of Educational Research, Vol. 68, No. 4 (Winter, 1998), pp. 413-449.

Kadijevich, D., \& Haapasalo, L. (2001). Linking procedural and conceptual mathematical knowledge through CAL. Journal of Computer Assisted Learning, 17(2), 156-165.

Kızılçaoğlu, A. (2006). Eğitim Fakültelerinde Yeniden Yapılandırma Sürecine İlişkin Eleştiriler ve Öneriler [Critics and suggestions on redevelopment processes of colleges of education]. Ballkesir Üniversitesi, Sosyal Bilimler Enstitüsü Dergisi, 8(14), 132 140.

Krapp, A. (1999). Interest, motivation and learning: An educational psychological perspective. European journal of Psychology of Education, 14, 23-40

Lauritzen, Pal (2012). Conceptual and Procedural Knowledge of Mathematical Functions. Publications of the University of Eastern Finland. 
Lemaire,P., Lecacheur,M. ve Farioli, F. (2000). Children's strategy use in computational estimation. Canadian Journal of Experimental Psychology, 2 (54), 141-148.

Leutzinger, Rathmell ve Urbatsch (1986). Developing estimation skills in the primary grades. In H.L. Schoen ve M.J. Zweng (Eds.) Estimation and mental computation. Yearbook 82-92. N.C.T.M. Reston, VA.

Levin, J. A. (1981). Estimation techniques for arithmetic: Everyday math and mathematics instruction. Education Studies in Mathematics, 12, 421-434.

Levine,D.J. (1982). Strategy, Use, and Estimation Ability of College Students, Journal for Research in Mathematics Education 13, 350-359.

Ma, L. (1999). Knowing and Teaching Elementary Mathematics Teachers' Understanding of Fundamental Mathematics in China and the United States. Mahwah, NJ: Erlbaum.

Maciejewski, W., Mgombelo, J. and Savard, A. (2011). Meaningful procedural knowldge in mathematics learning. CMESG/GCEDM Proceedings 2011. Working Group Report

Markovits, Z. and Herskovits, R. (1993). Visual estimation of discrete quantities. ZDM. 93/4, 137-140.

Markovitz, Z. (1987). Estimation Reseacrh and Curriculum development. Thesis submitted to the scientific council of the wiezmann Institute of Science Rehovat, Israel.

Marton, F., \& Säljö, R. (1976). On qualitative differences in learning: I. Outcome and process. British Journal of Educational Psychology, 46(1), 4-11.

McLaughin, J. (1981). Development of children's ability to judge relative numerosity. Journal of Experimental Child Psychology, 31, 103-114.

MoNE (1998). İlköğretim Okulu Matematik Dersi Öğretim Programı 6-7-8. Sınıflar [6-8 Grades elementary mathematics curriculum]. İstanbul. Milli Eğitim Basımevi.

MoNE (2009). 6-8.Sınıflar İlköğretim Matematik Öğretim Programı [6-8 Grades elementary mathematics curriculum].Ankara

MoNE (2013). Ortaokul matematik dersi öğretim program [Middle school mathematics curriculum in Turkey]. Ankara

MoNE, (2012). 12 Y1llık zorunlu eğitime yönelik uygulamalar [Practices for 12 years compulsory education in Turkey]. Genelge [Circular Letter]. Milli Eğitim Bakanlığ Özel Kalem Müdürlüğü.

National Education Statistics (2013). Milli Ĕ̈itim Örgün Ĕgitim İstatistikleri [Statistics for Turkey Ministry of National Education] . Resmi İstatistik Programı Yayınları.

National Council of Teachers of Mathematics (NCTM) (1989). Curriculum and evaluation standards for school mathematics. Reston, VA: NCTM.

National Council of Teachers of Mathematics (NCTM) (1996). Curriculum and evaluation standards for school mathematics. Reston, VA: NCTM.

National Council of Teachers of Mathematics (NCTM) (2000). Principles and standards for school mathematics.Reston, VA: NCTM.

O'Daffer, P. (1979). A case and techniques for estimation: Estimation experiences in elementary school mathematics - Essential, not extra! Arithmetic Teacher, 26, 46-51.

Olkun, S. ve Toluk Uçar, Z. (2006) .Illköğretimde Matematik Öğretimine Çağdaş Yaklaşımlar [Contemporary Approaches in Elementary Mathematics Education], Ankara:Ekinoks Yayınc1lik.

Pajera, J.L. (2001). Estimation de candidades discretas por alumnos de Magisteria (Memoria de Tercer Ciclo). Estimation of discrete quantities by preservice teachers (Third Cycle Report). Mathematics Didactics Department, University of Granada.

Piaget, J.L. and Szeminska, A. (1964). Genesis del numero en el nino, Guedalupe, Buenos Aires.

Reys, R,E. ve Bestgen, B,J. (1981). Teaching and assessing computational Estimation skills. The Elementary School Journal, 2(82), 116-127. 
Reys, R. E., Lindquist, M. M., Lambdin, D. V., \& Smith, N. L. (2009). Helping children learn mathematics (9th ed.). Danvars: John Wiley \& Sons.

Reys,Barbara J. , Reys Robert E. ve Penafiel, Alfinio Flores. (1991). Estimation performance and strategy use of mexican 5th and 8th grade student sample.Educational Studies in Mathematics, 22(4). 353-375.

Rubenstein, N.R.(1985). Computational Estimation and Related Mathematical Skills, Journal for Research in Mathematics Education, 16(2),106-119

Ryan, R. M., \& Deci, E. L. (2000). Intrinsic and Extrinsic Motivations: Classic Definitions and New Directions. Contemporary Educational Psychology, 25, 54-67.

Schoenfeld, A. H. (1982). Learning to Think Mathematically: Problem Solving, Metacognition, and Sense Making in Mathematics. In D. A. Grouws (Ed.), Handbook of Research on Mathematics Teaching and Learning: a Project of the National Council of Teachers of Mathematics. New York: Macmillan, 334-370.

Schoenfeld, A. H. (1990). A source book for college mathematics teaching. Washington DC: Mathematical Association of America.

Segovia, I. (1997). Estimación de cantidades discretas. Estudio de variables y procesos. Granada: Comares.

Segovia, I. ve Castro,E. (2009), Computational and measurement estimation; curriculum foundations and research carried out at the University of Granada. Electronic Journal of Research in Educational Psyhology, 17(7),499-536.

Siegel, A. W., Goldsmith, L. T., ve Madson, C. R. (1982). Skill in estimation problems of extent and numerosit. Journal for Research in Mathematics Education, 3(13), 211232.

Sowder, J., ve Wheeler, M. (1989). The development of concepts and strategies usedin computational estimation. Journal for Research in Mathematics Education, 20, 130146.

Sriraman, B. ve Knott, L. (2009). The Mathematics of Estimation: Possibilities for Interdisciplinary Pedagogy and Social Consciousness. Interchange, Vol. 40/2, 205223.

Tekinkır, D. (2008). İlköğretim 6-8.Sınıf Öğrencilerinin Matematik Alanındaki Tahmin Stratejilerini Belirleme Ve Tahmin Becerisi İle Matematik Başarısı Arasındaki İlişki [To determine the estimate strategies in maths field for the primary school studens of 6th-8th grades and the relation between the estimate ability and success for maths]. Yayımlanmamıış Yüksek Lisans Tezi, İzmir: Dokuz Eylül Üniversitesi Eğitim Bilimleri Enstitüsü.

Van de Walle, J. A., Karp, K. S., ve Bay-Williams, J. M. (2010). Elementary and middle school mathematics: Teaching developmentally. Boston, MA: Allyn \& Bacon.

Volkova, Tanya N. (2005). Characterizing Middle School Students Thinking İn Estimation. Proceedings of the 29th Conference of the International Group for the Psychology of Mathematics Education, Vol. 4, pp. 289-296. Melbourne: PME.

Wæge, Kjersti (2009). Relations between students' motivation for learning mathematics and a mathematical teaching approach. Nordic Research in Mathematics Education.

Wedege, T., \& Evans, J. (2006). Adults' resistance to learning in school versus adults' competences in work: The case of mathematics. Adults learning mathematics, 1(2), 28-43.

Workman, J.E. ve Ahn, I. (2011). Linear Measurement and Linear Measurement Estimation Skills in Apparel Design. Clothing \& Textiles Research Journal 29(2) 150-164.

Yates, S. M. (2000). Student optimism, pessimism, motivation and achievement in mathematics: A longitudinal study. In T. Nakahara \& M. Koyama (Eds.), Proceedings 
of the 24th Conference of the International Group for the Psychology of Mathematics Education (Vol. 4, pp. 297-304). Japan: Hiroshima University. 